\title{
Purification of Oligodendrocyte Lineage Cells from Mouse Cortices by Immunopanning
}

\author{
Ben Emery ${ }^{1,4}$ and Jason C. Dugas ${ }^{2,3}$ \\ ${ }^{1}$ Department of Anatomy and Neuroscience and the Florey Institute of Neuroscience and Mental Health, \\ University of Melbourne, Melbourne, Victoria 3010, Australia; ${ }^{2}$ Myelin Repair Foundation, Saratoga, California \\ 95070; ${ }^{3}$ Department of Neurobiology, School of Medicine, Stanford University, Stanford, California 94305-5125
}

Oligodendrocytes are the myelinating cells of the vertebrate central nervous system, responsible for generating the myelin sheath necessary for saltatory conduction. The use of increasingly sophisticated genetic tools, particularly in mice, has vastly increased our understanding of the molecular mechanisms that regulate development of the oligodendrocyte lineage. This increased reliance on the mouse as a genetic model has led to a need for the development of culture methods to allow the use of mouse cells in vitro as well as in vivo. Here, we present a protocol for the isolation of different stages of the oligodendrocyte lineage, oligodendrocyte precursor cells (OPCs) and/or postmitotic oligodendrocytes, from the postnatal mouse cortex using immunopanning. This protocol allows for the subsequent culture or biochemical analysis of these cells.

It is essential that you consult the appropriate Material Safety Data Sheets and your institution's Environmental Health and Safety Office for proper handling of equipment and hazardous material used in this protocol.

RECIPES: Please see the end of this article for recipes indicated by $<R>$. Additional recipes can be found online at http://cshprotocols.cshlp.org/site/recipes.

Reagents

Antibodies

Anti-PDGFRa antibody (e.g., rat anti-mouse CD140A; BD Pharmingen 558774)

Goat anti-mouse IgG + IgM (Jackson ImmunoResearch 115-005-044)

Goat anti-rat IgG (Jackson ImmunoResearch 112-005-167)

BSA stock $(4 \%)$

To prepare a stock of 4\% BSA in Dulbecco's phosphate-buffered saline (D-PBS), dissolve $8 \mathrm{~g}$ of BSA (Sigma-Aldrich A4161) in $150 \mathrm{~mL}$ of D-PBS (HyClone SH30264.01) at $37^{\circ} \mathrm{C}$. Adjust the pH to 7.4 with $\sim 1 \mathrm{~mL}$ of $1 \mathrm{~N} \mathrm{NaOH}$. Bring the volume to $200 \mathrm{~mL}$. Filter through a 0.22- $\mu \mathrm{m}$ filter. Store in 1-mL aliquots at $-20^{\circ} \mathrm{C}$.

BSL1 (Vector Laboratories L1100)

\footnotetext{
${ }^{4}$ Correspondence: emeryb@unimelb.edu.au

(c) 2013 Cold Spring Harbor Laboratory Press

Cite this article as Cold Spring Harb Protoc; 2013; doi:10.1101/pdb.prot073973
} 
DMEM-SATO base growth medium $<\mathrm{R}>$

DNase I

On ice, dissolve 12,500 U of DNase I (Worthington Biochemical LS002007) per $1 \mathrm{~mL}$ of chilled Earle's Balanced Salt Solution (EBSS; Invitrogen 14155-063). Filter-sterilize on ice. Aliquot (e.g., $200 \mu L / t u b e)$ and freeze overnight at $-20^{\circ} \mathrm{C}$. Store aliquots at $-20^{\circ} \mathrm{C}$ to $-30^{\circ} \mathrm{C}$.

Dulbecco's phosphate-buffered saline (D-PBS) with phenol red Add $500 \mu \mathrm{L}$ of $0.5 \%$ phenol red (Sigma-Aldrich P0290) per $500 \mathrm{~mL}$ bottle of Dulbecco's phosphatebuffered saline (D-PBS; Invitrogen 14287-080).

Dulbecco's phosphate-buffered saline (D-PBS) without $\mathrm{Ca}^{2+} / \mathrm{Mg}^{2+}$ (Invitrogen 14190-144) IMPORTANT: D-PBS without $\mathrm{Ca}^{2+} / \mathrm{Mg}^{2+}$ is ONLY used at the tissue dissection step (see Steps 10 and 17). All other steps in the protocol refer to the standard D-PBS with phenol red. Cells will not stick to the panning plates in the $\mathrm{Ca}^{2+}-\mathrm{Mg}^{2+}$-free $D-P B S$.

Earle's balanced salt solution (EBSS) (Invitrogen 14155-063)

Ethanol (70\%)

Ethanol-washed glass coverslips (optional) $<\mathrm{R}>$

Prepare $\sim 1$ mo in advance.

Fetal calf serum (FCS) (heat-inactivated)

Prepare 50-mL aliquots of fetal calf serum (Invitrogen 16000-036) in sterile conical tubes. Heat-inactivate aliquots for $30 \mathrm{~min}$ in a $55^{\circ} \mathrm{C}$ water bath, then store at $-20^{\circ} \mathrm{C}$.

High-ovomucoid (high-ovo) stock $(6 \times)<\mathrm{R}>$

Hybridoma supernatants

Anti-galactocerebroside (GalC) hybridoma supernatant (for all postmitotic $\left[\mathrm{GalC}^{+}\right]$oligodendrocytes)

Anti-MOG hybridoma supernatant (for mature $\left[\mathrm{MOG}^{+}\right]$oligodendrocytes)

Insulin stock $(0.5 \mathrm{mg} / \mathrm{mL})<\mathrm{R}>$

L-cysteine (Sigma-Aldrich C-7477)

Low-ovomucoid (low-ovo) stock solution $(10 \times)<\mathrm{R}>$

Mouse pups

One P7 mouse brain should yield about $0.5 \times 10^{6}$ OPCs; this yield will decline as the age of the animal increases. If purifying postmitotic oligodendrocytes, the yield is best at $\sim P 12-P 16$. Beyond this age, dissociation of the tissue becomes progressively more difficult and the yield and viability of both OPCS and postmitotic oligodendrocytes are reduced.

If more than three pups are to be used, then the solutions and panning dish numbers will need to be increased. If several brains are to be processed in parallel (e.g., to compare two genotypes), adjust the number of panning plates and volumes of solutions accordingly.

OPC culture medium $<\mathrm{R}>$

Addition of PDGF and NT-3 to medium in the absence of T3 will promote OPC proliferation, whereas addition of $T 3$ to medium in the absence of PDGF and NT-3 will promote rapid OL differentiation. Robust differentiation will also commence in medium lacking both mitogens (PDGF and NT-3) and T3, but viability will be poor.

Papain (Worthington Biochemical LS003126)

Papain buffer $<\mathrm{R}>$

Phenol red solution (0.5\%) (Sigma-Aldrich P0290)

Phosphate-buffered saline (PBS) (filter- or autoclave-sterilized)

Poly-D-lysine (PDL) stock $(1 \mathrm{mg} / \mathrm{mL})<\mathrm{R}>$

The $1 \mathrm{mg} / \mathrm{mL}$ solution is a $100 \times$ stock. Dilute it to $1 \times$ in sterile $\mathrm{H}_{2} \mathrm{O}$ before use.

Tris- $\mathrm{HCl}$ (50 mm, pH 9.5) (filter- or autoclave-sterilized)

Trypan blue (Invitrogen 15250-061)

Trypsin stock $<\mathrm{R}>$

For each new batch of trypsin stock, the optimal trypsinization time required to release cells from the final panning plate (Step 52) should be redetermined. 
B. Emery and J.C. Dugas

Equipment

$5 \% \mathrm{CO}_{2} / 95 \% \mathrm{O}_{2}$ source (with a line leading to a heat block in a sterile hood)

Centrifuge (tabletop, with $15-\mathrm{mL} / 50-\mathrm{mL}$ conical tube adaptors)

Conical tubes (15- and 50-mL, sterile)

Flasks $\left(175-\mathrm{cm}^{2}\right)$ (optional)

Forceps (\#5 or \#55)

Heat block base (with a flat insert set to $34^{\circ} \mathrm{C}$ in a sterile hood)

Hemocytometer slide (Hausser Scientific 3110)

Laminar flow tissue culture hood

Monoject syringes (sterile) (Fisher Scientific)

Nitex mesh filters

Nitex mesh 20- $\mu$ m opening filters can be ordered from Amazon. Cut filters into approximately 3 inch $\times 3$ inch squares. Wrap sets of 8 to 12 in aluminum foil and autoclave to sterilize.

Petri dish lid $(6-\mathrm{cm}$, with a hole in the center to accommodate a $0.22-\mu \mathrm{m}$ filter)

Create the hole using flamed forceps to melt an opening into the center of the lid, or use a drill.

Petri dishes (6-, 10-, and 15-cm) (Falcon or Nunc)

Tissue-culture incubator (set to $37^{\circ} \mathrm{C}, 10 \% \mathrm{CO}_{2}$ )

Scalpel blade handle

Scalpel blades (\#10)

Scissors (large, for decapitation) (e.g., Roboz RS-6820)

Scissors (small, curved) (e.g., Roboz RS-5675)

Syringe filters $(0.22-\mu \mathrm{m})$

Tissue-culture plates (plastic) (6- or 24-well) (Falcon or Nunc) (optional)

Water bath (set to $37^{\circ} \mathrm{C}$ )

An overview of the method is provided in Figure 1. For any steps that require filter sterilization of reagents before use, prerinse the filter with 5-10 mL of base liquid (e.g., D-PBS) to remove any residual surfactants that may be detrimental to cell health. Discard the prefilter liquid before filtering the solution to be sterilized.

Preparation of Plates and Reagents

Perform Step 1 on the day before cell purification. Steps 2-5 can be performed the day before or the same day as cell purification. (PDL-coated coverslips and tissue culture plates are usable up to $6 \mathrm{~d}$ following preparation.) For users familiar with the protocol, Steps 2-5 also may be performed during the 90-min papain digestion (Step 21) or panning steps (Steps 39-43) to save time.

1. Coat the panning dishes with secondary antibodies as follows.

i. For OPCs $\left(\mathrm{PDGFRa}^{+}\right)$, coat a 10 -cm Petri dish with $30 \mu \mathrm{L}$ of goat anti-rat IgG plus $10 \mathrm{~mL}$ of sterile $50 \mathrm{~mm}$ Tris- $\mathrm{HCl}(\mathrm{pH}$ 9.5).

ii. For mature $\left(\mathrm{MOG}^{+}\right)$oligodendrocytes, coat a 10 -cm Petri dish with $30 \mu \mathrm{L}$ of goat antimouse IgG + IgM plus $10 \mathrm{~mL}$ of sterile $50 \mathrm{~mm}$ Tris- $\mathrm{HCl}(\mathrm{pH}$ 9.5).

iii. For all postmitotic $\left(\mathrm{GalC}^{+}\right)$oligodendrocytes, coat a $10-\mathrm{cm}$ Petri dish with $30 \mu \mathrm{L}$ of goat anti-mouse IgG + IgM plus $10 \mathrm{~mL}$ of sterile $50 \mathrm{~mm}$ Tris- $\mathrm{HCl}$ (pH 9.5).

iv. Swirl the plates until the surfaces are evenly coated with the antibody-Tris solution.

v. Incubate the panning plates overnight at $4^{\circ} \mathrm{C}$.

One set of panning plates and reagents is sufficient for one to three postnatal mouse brains.

2. If the isolated cells will be cultured at the end of the protocol, prepare the culture dishes as follows.

i. Add $15 \mathrm{~mL} / 5 \mathrm{~mL} / 1 \mathrm{~mL} / 250 \mu \mathrm{L}$ of $1 \times$ PDL per well to a $175-\mathrm{cm}^{2}$ flask / $10-\mathrm{cm}$ dish / six-well plate / 24-well plate, respectively. 


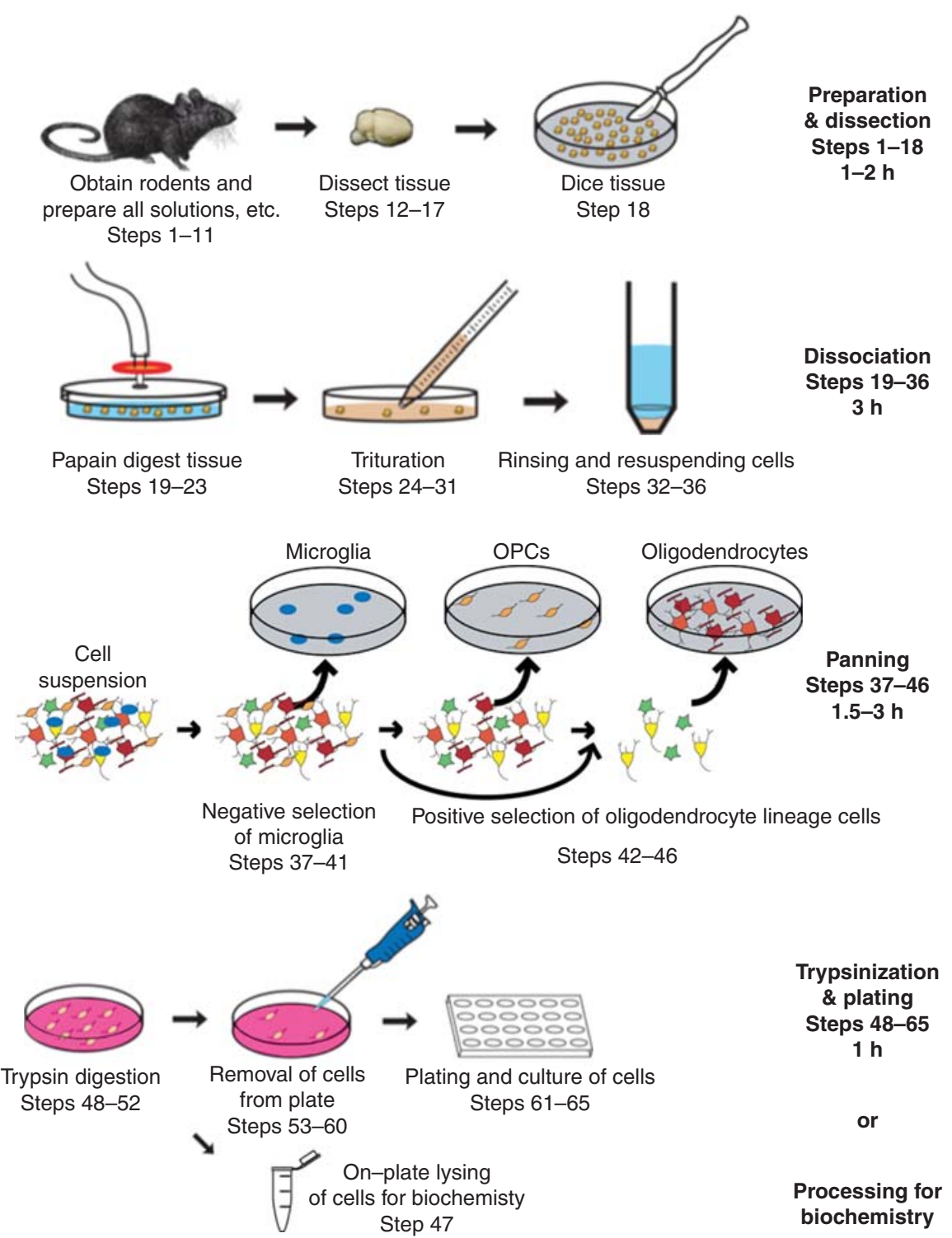

FIGURE 1. Purification of oligodendrocyte lineage cells by immunopanning.

ii. Swirl to evenly coat plastic.

iii. Incubate for 20-60 min at room temperature or at $4^{\circ} \mathrm{C}$ overnight.

iv. Rinse plates three times with sterile $\mathrm{H}_{2} \mathrm{O}$.

v. Allow plates to completely air-dry before use.

3. If the isolated cells will be cultured at the end of the protocol, prepare the coverslips as follows.

i. Rinse the ethanol-washed glass coverslips three times with sterile $\mathrm{H}_{2} \mathrm{O}$ in a Petri dish.

ii. After the last rinse, suction away the remaining $\mathrm{H}_{2} \mathrm{O}$ and separate the coverslips in the plate such that they are not touching each other or the sides of the plate.

iii. Allow the coverslips to completely air-dry.

This should take 5-10 min after suctioning.

iv. Carefully add $100 \mu \mathrm{L}$ of $1 \times$ PDL to the center of each coverslip.

The PDL solution should remain as a bubble on the coverslip. 
B. Emery and J.C. Dugas

v. Incubate for 30-60 $\mathrm{min}$ at room temperature or at $4^{\circ} \mathrm{C}$ overnight.

vi. Rinse the coverslips three times with sterile $\mathrm{H}_{2} \mathrm{O}$.

vii. Transfer the coverslips to 24-well tissue culture plates, placing one coverslip per well.

viii. Suction any remaining $\mathrm{H}_{2} \mathrm{O}$ from the wells, being careful to keep the coverslips centered and not touching the sides of the wells.

If the coverslips contact the sides of the wells, the preplating of the cells will not work.

ix. Allow the coverslips to completely air-dry before use.

4. Prepare $40 \mathrm{~mL}$ of $0.2 \%$ BSA solution by adding $2 \mathrm{~mL}$ of $4 \%$ BSA stock to $38 \mathrm{~mL}$ of D-PBS. Store at $4^{\circ} \mathrm{C}$.

5. Prepare the DMEM-SATO base medium (or the desired medium) for the cells.

\section{Preparation for Cell Purification}

Perform Steps 6-11 on the day of cell purification. For users familiar with the protocol, Step 11 also may be performed during the 90-min papain digestion (Step 21) to save time.

Do not allow the plates to dry at any stage.

6. Coat two 15-cm dishes with BSL1 as follows.

i. Dilute $40 \mu \mathrm{L}$ of BSL1 in $40 \mathrm{~mL}$ of D-PBS.

ii. Add $20 \mathrm{~mL}$ per dish and swirl to cover the entire surface.

7. Coat the panning dishes with primary antibodies as follows.

i. Rinse each antibody-coated dish (prepared in Step 1) three times with PBS.

ii. For anti-PDGFRa, add $12 \mathrm{~mL}$ of $0.2 \%$ BSA in D-PBS (prepared in Step 4) and $40 \mu \mathrm{L}$ of rat anti-PDGFRa to a goat anti-rat IgG-coated dish from Step 1 and let sit at room temperature until use.

iii. For anti-GalC, add $8 \mathrm{~mL}$ of $0.2 \%$ BSA in D-PBS and $4 \mathrm{~mL}$ of mouse anti-GalC supernatant to a goat anti-mouse IgG + IgM-coated dish from Step 1 and let sit at room temperature until use.

iv. For anti-MOG, add $8 \mathrm{~mL}$ of $0.2 \% \mathrm{BSA}$ in D-PBS and $4 \mathrm{~mL}$ mouse anti-MOG supernatant to a goat anti-mouse IgG + IgM-coated dish from Step 1 and let sit at room temperature until use.

v. Swirl to evenly coat plastic.

vi. Incubate for $>2 \mathrm{~h}$ at room temperature.

8. Equilibrate $10 \mathrm{~mL}$ of papain buffer in a 6-mL Petri dish as follows.

i. Presterilize a 6-cm dish lid with a central hole by spraying with $70 \%$ ethanol. Let air-dry.

ii. Place the 6 -cm dish containing papain buffer on a $34^{\circ} \mathrm{C}$ heat block in a sterile hood.

iii. Place a $0.22-\mu \mathrm{m}$ filter at the end of a $5 \% \mathrm{CO}_{2} / 95 \% \mathrm{O}_{2}$ line and place the sterile end of the filter through the hole in the sterilized lid.

iv. Place the lid supplying gas over the papain buffer dish in the heat block and supply a gentle flow of gas.

9. Place $10 \mathrm{~mL}$ of EBSS containing $0.0005 \%$ phenol red into a $10 \% \mathrm{CO}_{2}$ incubator to equilibrate.

10. Add $\sim 300 \mu \mathrm{L}$ of D-PBS without $\mathrm{Ca}^{2+} / \mathrm{Mg}^{2+}$ to a 6-cm Petri dish (or, alternatively, each well of a six-well plate).

If several brains are to be processed in parallel (e.g., to derive cells from several pups of different genotypes), Steps 17-21 can be carried out in a six-well plate, with one brain per well and a single hole in the lid for gas flow. 
11. Prepare the solutions for dissociation, panning and trypsinization as follows.

i. Prepare low-ovo working solution by adding $1 \mathrm{~mL}$ of $10 \times$ low-ovo stock to $9 \mathrm{~mL}$ of D-PBS.

ii. Prepare high-ovo working solution by adding $1 \mathrm{~mL}$ of $6 \times$ high-ovo stock to $5 \mathrm{~mL}$ of $\mathrm{D}$-PBS.

iii. Prepare panning buffer by combining $1.5 \mathrm{~mL}$ of $0.2 \%$ BSA solution, $13.5 \mathrm{~mL}$ of D-PBS, and $150 \mu \mathrm{L}$ of insulin stock $(500 \mu \mathrm{g} / \mathrm{mL})$.

iv. Add $3 \mathrm{~mL}$ of heat-inactivated FCS to $7 \mathrm{~mL}$ of D-PBS and filter through a $0.22-\mu \mathrm{m}$ filter to sterilize.

The phenol red color of the low- and high-ovo solutions should be orange (neutral $\mathrm{pH}$ ) rather than red (too basic) or yellow (too acidic). If necessary, sterile $1 \mathrm{~m} \mathrm{NaOH}$ can be used to equilibrate both solutions back to neutral $\mathrm{pH}$.

\section{Dissection}

See online Movie 1 at cshprotocols.cshlp.org for an illustration of Steps 13-18.

12. Decapitate the mouse $\operatorname{pup}(\mathrm{s})$ with sharp scissors.

13. Cut the skin along the top midline of the head, and peel back to reveal the skull.

14. Use curved scissors to open the skull: Insert the scissors at the opening at the back of the skull and cut along the left and right edge of the skull, above the ear to just above the eye socket.

15. Lift the skull bone to reveal the brain.

16. Cut away the olfactory bulbs at the front of the brain, and then remove the rest of the brain. The specific brain region of interest can also be dissected at this stage.

17. Place the brain in $300 \mu \mathrm{L}$ of D-PBS without $\mathrm{Ca}^{2+} / \mathrm{Mg}^{2+}$ in the dish prepared in Step 10.

18. Dice the tissue with a $\# 10$ scalpel into $\sim 1-\mathrm{mm}^{3}$ chunks.

Tissue Dissociation

19. Prepare the papain solution.

i. Move the equilibrated papain buffer prepared in Step 8 to a $15-\mathrm{mL}$ conical tube and add 200 units of papain.

ii. Place this papain solution in a $37^{\circ} \mathrm{C}$ water bath for $5-15 \mathrm{~min}$ to allow the papain to dissolve.

iii. Weigh out and add $2 \mathrm{mg}$ of $\mathrm{L}$-cysteine to the solution.

iv. When fully dissolved, filter the papain solution through a $0.22-\mu \mathrm{m}$ filter to sterilize.

v. Add $200 \mu \mathrm{L}$ of DNase I stock solution to the papain solution.

20. Add the papain solution from Step 19 directly to the diced brain tissue in the 6-cm Petri dish. Place the dish in an empty heat block at $34^{\circ} \mathrm{C}$, and then cover with the same lid used to equilibrate the papain solution.

21. Keep the tissue under $5 \% \mathrm{CO}_{2} / 95 \% \mathrm{O}_{2}$ gas flow at $34^{\circ} \mathrm{C}$ for $90 \mathrm{~min}$, gently agitating the tissue every 15 min to ensure complete tissue digestion.

Brain dissociation digestions performed at $34^{\circ} \mathrm{C}$ slightly increase the health of the cells obtained compared to digestions at $37^{\circ} \mathrm{C}$.

22. Just before the digestion step is complete, add $100 \mu \mathrm{L}$ of DNase I stock solution to the low-ovo working solution prepared in Step 11.

23. When the digestion is complete, transfer the tissue in papain solution to a sterile $15-\mathrm{mL}$ conical tube and allow the tissue pieces to settle.

24. Carefully remove as much papain solution as possible from the tissue.

25. Gently add $2 \mathrm{~mL}$ of low-ovo solution with DNase I from Step 22 to the tissue to stop papain digestion. Allow the tissue to settle once again. 
B. Emery and J.C. Dugas

26. Remove and discard the low-ovo solution from the tissue.

27. Add $2 \mathrm{~mL}$ of fresh low-ovo solution with DNase I to the tissue.

Dissociation is performed in low-ovo solution because the cells survive trituration better in a lower protein solution. High-ovo is subsequently used to fully quench any residual papain enzymatic activity.

28. Dissociate the brain tissue as follows (see online Movie 2 at cshprotocols.cshlp.org).

i. Gently pipette the tissue six to eight times through a 5-mL pipette.

ii. Let the tissue chunks settle for 1-2 min.

iii. Remove 1-1.5 $\mathrm{mL}$ of the resulting cell suspension, trying to avoid large tissue chunks. Place the collected cell suspension in a new, sterile $15-\mathrm{mL}$ conical tube.

iv. Add $1 \mathrm{~mL}$ of low-ovo solution with DNase I, and repeat Steps 28.i-28.iii.

v. Add $1 \mathrm{~mL}$ of low-ovo solution with DNase I, and then follow Steps 28.i-28.iv, now triturating tissue through a 1-mL pipette tip. Repeat until all of the tissue is dissociated and the low-ovo solution prepared in Step 22 is used up.

29. (Optional) To determine cell viability and the effectiveness of the dissociation at this stage, remove a small aliquot $(50-100 \mu \mathrm{L})$ of cell suspension for counting. Count as described in Step 61.

See Troubleshooting.

30. Pellet the cells at $\sim 220 \mathrm{~g}$ for $15 \mathrm{~min}$ in a tabletop centrifuge at room temperature.

31. Aspirate the supernatant, being careful not to disturb the cell pellet.

32. Resuspend the cell pellet in $6 \mathrm{~mL}$ of high-ovo solution prepared in Step 11.

33. Immediately pellet the cells at $\sim 220 \mathrm{~g}$ for $15 \mathrm{~min}$ in a tabletop centrifuge at room temperature. Leaving cells for an extended period of time in high-ovo solution will reduce cell viability.

34. Aspirate the supernatant, being careful not to disturb the cell pellet.

35. Resuspend the cell pellet in $6 \mathrm{~mL}$ of panning buffer prepared in Step 11.

36. Prewet a sterile Nitex mesh filter by filtering $2 \mathrm{~mL}$ of panning buffer into a sterile $50-\mathrm{mL}$ tube. Filter the cells into the tube $1 \mathrm{~mL}$ at a time, then rinse the filter with the remaining panning buffer.

\section{Panning}

Do not allow plates to dry out at any stage.

37. Immediately before panning dish use, rinse the panning dish three times with D-PBS.

38. Add the cell suspension from Step 36 to the first rinsed BSL1 dish prepared in Step 6.

39. Incubate the plate for $15 \mathrm{~min}$ at room temperature, agitating the plate at 5 -min intervals to ensure that all cells have an opportunity to adhere to the plate surface.

40. Gently shake the plate to loosen nonadherent cells, and transfer the cell suspension to the second rinsed BSL1 dish prepared in Step 6.

41. Repeat Step 39.

42. Gently shake the plate to loosen nonadherent cells, and transfer the cell suspension to the first rinsed positive selection dish (e.g., anti-PDGFRa or anti-GalC) prepared in Step 7.

43. Incubate the plate for $45 \mathrm{~min}$ at room temperature, agitating the plate every $15 \mathrm{~min}$ to ensure that all cells have an opportunity to adhere to the plate surface.

44. Shake the plate to loosen nonadherent cells.

If subsequent panning steps are to be performed, cell suspension should be kept and transferred to the next panning dish. If only one positive selection is to be used, the cell suspension can be discarded. 
45. Rinse the plate six times with D-PBS, shaking the plate at each rinse to loosen nonadherent cells. OPCs often bind relatively weakly to the anti-PDGFRa plate, so wash gently, pouring the D-PBS onto the same place on the plate each time.

46. For each positive selection plate, repeat Steps 43-45.

The subsequent trypsinization or lysing steps can be carried out during the 45 min incubation for the next plate.

47. Proceed to Step 48 if cells are to be cultured. Alternatively, to lyse cells for biochemistry, remove all liquid after the final wash. Add RNA or protein lysis buffer directly to the panning dish on ice. Scrape the lysates with a rubber policeman and transfer to a $1.5-\mathrm{mm}$ microcentrifuge tube for further processing.

\section{Trypsinization}

See online Movie 3 at cshprotocols.cshlp.org for an illustration of Steps 54 and 55.

48. Before trypsinization, confirm visually under the microscope that nearly all nonadherent cells have been removed by rinsing. If needed, perform additional rinsing steps.

There will always be a small number $(<0.5 \%)$ of dislodged floating cells at the end of the rinsing steps, especially when using anti-PDGFRa.

See Troubleshooting.

49. Once the cells are in their final D-PBS rinse, transfer $4 \mathrm{~mL}$ of the equilibrated EBSS prepared in Step 9 to a sterile tube and add $400 \mu \mathrm{L}$ of trypsin stock solution.

50. Remove the D-PBS from the plate and rinse the plate with the remaining $6 \mathrm{~mL}$ of equilibrated EBSS.

51. Pour off the EBSS and add the $4 \mathrm{~mL}$ of trypsin-EBSS solution prepared in Step 49.

52. Incubate the plate for $6-8 \mathrm{~min}$ in a $37^{\circ} \mathrm{C}$ incubator.

Optimal trypsinization time should be determined with each batch of stock trypsin solution generated, and should correspond to the time at which a large percentage of cells on the plate can be easily released by gentle pipetting. Trypsinization times that are either too short or too long can result in reduced cell viability.

53. Add $2 \mathrm{~mL}$ of the filtered $30 \%$ FCS solution prepared in Step 11 to the plate to stop trypsin digestion.

54. Dislodge the cells from the plate surface by squirting the FCS solution around the plate using a 1-mL pipette tip: Squirt the solution once around the entire circumference toward the center of the dish, once along the edge of the entire dish, and then once concentrating on center. Avoid scraping the tip of the pipette along the surface of the plate; instead squirt just above the surface. Avoid generating excess bubbles in the solution during squirting.

55. Remove the cell suspension from the plate and place it in a sterile $15-\mathrm{mL}$ conical tube.

56. Place $5 \mathrm{~mL}$ of fresh $30 \%$ FCS in the plate and visualize the plate under the microscope to determine if there are particular regions of the plate that still contain adherent cells.

Adherent cells are often found along the edges or in the exact center of the plate.

57. Repeat Steps 54 and 55 to dislodge and collect the remaining cells.

58. Rinse the plate with the remaining FCS and add the solution to the collection tube to collect the last remaining cells.

59. Remove a 50- to $100-\mu \mathrm{L}$ aliquot of the cell suspension for counting.

60. Pellet the cells at $\sim 220 \mathrm{~g}$ for $15 \mathrm{~min}$ in a tabletop centrifuge at room temperature.

61. During Step 60, determine yield by adding an equal volume of trypan blue to the cell suspension aliquot from Step 59 and count the cells on a hemocytometer slide.

Expected yields are as follows:

One P6-8 mouse brain, $0.5 \times 10^{6} \mathrm{PDGFRa}^{+} \mathrm{OPCS}$ 
B. Emery and J.C. Dugas

One $P 12$ mouse brain, $1 \times 10^{6} \mathrm{GalC}^{+} \mathrm{OLS}$

See Troubleshooting.

62. After centrifugation, aspirate the supernatant and resuspend the cell pellet in a small volume of DMEM-SATO base growth medium.

Plating

OPCs are typically plated at a density of 10,000-20,000 /coverslip in 24-well plate wells, 500,000 per 80-cm² flask or $1 \times 10^{6}$ cells per $175-\mathrm{cm}^{2}$ flask for proliferation. Mature cells are usually plated at a density of 40,000-50,000/ coverslip in 24-well plate wells.

63. Preplate the cells as follows.

Coverslips

i. Adjust the volume of the cell suspension in DMEM-SATO base growth medium to the number of desired cells per well/50 $\mu \mathrm{L}$ medium.

ii. Place a $50-\mu \mathrm{L}$ spot of cell suspension at the center of the individual coverslips prepared in Step 3.

iii. Incubate for $20-45 \mathrm{~min}$ at $37^{\circ} \mathrm{C}$ to let the cells adhere to the coverslips.

iv. Add the desired medium at $500 \mu \mathrm{L} /$ well (see Step 64).

\section{Tissue Culture Plates}

i. Adjust the volume of the cell suspension in DMEM-SATO base growth medium to the number of desired cells per plate $/ 300 \mu \mathrm{L}$ medium.

ii. Pipette $300 \mu \mathrm{L}$ of cell suspension into a 10-cm PDL-coated tissue culture plate prepared in Step 2 and carefully spread the liquid with a sterile glass spreader, trying to avoid scraping the glass spreader on the plastic bottom of the plate.

iii. Incubate for $7 \mathrm{~min}$ at $37^{\circ} \mathrm{C}$ to let the cells adhere to plate.

iv. Add the desired medium at $10 \mathrm{~mL} /$ plate (see Step 64).

v. Alternatively, add the number of cells to be plated to $10 \mathrm{~mL}$ of the desired medium and add the solution directly to the PDL-coated $10-\mathrm{cm}$ tissue culture plate.

This method results in slightly lower initial cell viability.

64. Prepare OPC culture medium according to the cells used and the desired result.

The addition of PDGF, NT-3 and/or T3 may be added to the culture medium to promote proliferation and/or differentiation (Fig. 2).

65. Incubate the $\mathrm{OPC}$ cultures at $37^{\circ} \mathrm{C}, 10 \% \mathrm{CO}_{2}$; replace $50 \%$ of the medium with fresh medium every $2-3 \mathrm{~d}$.

To generate highly dense cultures of OPCs, we recommend using $20 \mathrm{ng} / \mathrm{mL}$ of PDGF (2x normal concentration) as the OPC cultures begin to get dense (>25\% confluency) to avoid unwanted differentiation. In addition, supplemental PDGF can be added directly to the cultures between feedings.

If differentiating OPCs into mature oligodendrocytes via removal of PDGF and addition of T3, a more rapid and synchronized differentiation can be obtained by passaging the cells into a new flask, rather than simply replacing the medium.

See Troubleshooting.

Problem (Step 48): Microglial contamination is present.

Solution: Microglial contamination is caused by insufficient depletion of microglia by the BSL1 dishes. Microglia are usually easily identifiable on the positive selection dishes because of their "poached egg" appearance, in contrast to the rounded OPCs or oligodendrocytes. To avoid 
A

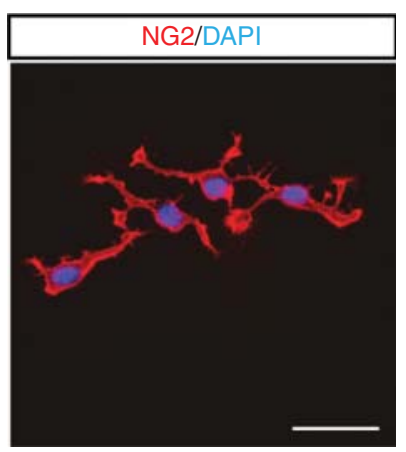

B

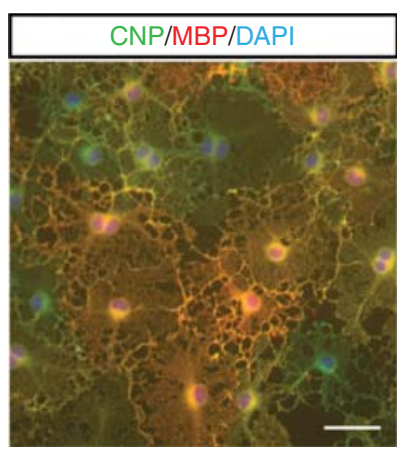

FIGURE 2. Mouse oligodendrocyte lineage cells in culture. (A) OPCs purified via immunopanning for PDGFRa and cultured in the presence of PDGF. (B) Differentiating oligodendrocytes $48 \mathrm{~h}$ following removal of PDGF and addition of T3. Cells have dramatically changed their morphology, and they all express CNP and are in the process of upregulating MBP. NG2, NG2 chondroitin sulfate proteoglycan; CNP, 2',3'-cyclic-nucleotide 3'-phosphodiesterase; MBP, myelin basic protein. Scale bars, $10 \mu \mathrm{m}$.

contamination, either decrease the number of brains used or increase the number or size of the BSL1 dishes. Petri dishes of $15 \mathrm{~cm}$ instead of $10 \mathrm{~cm}$ can be used to increase the surface area (while increasing the volume of panning buffer to $15-20 \mathrm{~mL}$ ), or additional BSL1 dishes can be added. If more dishes are added, reduce the total panning time by splitting the cell suspension into two and passing it over two BSL1 dishes in parallel before combining for the final positive selection dishes.

Problem (Steps 29 and 61): The final yield of cells is low.

Solution: Check the cell count of the total brain supernatant collected in Step 29. For whole brain, the yield at this step should be $20 \times 10^{6}$ total cells. If the yield is much lower, the dissociation steps (Steps 20-28) may have been the problem: Either the tissue was not sufficiently dissociated (if there are very few cells), or the trituration was too rough (if there is a very high percentage of trypan blue-positive dead cells). In addition, if the papain enzyme is bad, dissociation will be unsuccessful.

Problem (Steps 48 and 61): The final yield of cells is low and the cells were not very dense on the final planning plate at Step 48.

Solution: If the dissociation count in Step 29 is satisfactory, the next most likely source of the problem is the panning plates. If the cells were not very dense on the final panning plate at Step 48, there are several potential reasons.

- The cells were unhealthy and did not stick to the plate, possibly because of subtle problems in the trituration steps.

- The cells were rinsed too robustly. (This is especially relevant for anti-PDGFRa plates, but less so for anti-GalC or anti-MOG plates.)

- The panning buffer was made with D-PBS lacking $\mathrm{Ca}^{2+} / \mathrm{Mg}^{2+}$, or insulin was not added to the panning buffer. Either of these errors will lead to the cells not adhering strongly to the panning plates.

- The protocol was initiated using too much tissue and, thus, there was too much tissue in the panning plates. Excessive cells will block the surface of the plate and prevent the target cells from contacting and adhering to the plate surface.

Problem (Step 61): The final yield of cells is low, but the pretrypsinization density of cells on the final panning plate was high. 
B. Emery and J.C. Dugas

Solutions: If the pretrypsinization density of cells was high at Step 48, then the trypsinization and final rinsing step might be a problem.

- If the trypsin solution is too weak, or if the trypsinization time is too short, it is very difficult to dislodge the cells from the final panning plate. In addition, cells that are dislodged will be unhealthy, leading to a low final yield. If after $10 \mathrm{~min}$ the cells are still stuck very strongly to the plate, try adding more trypsin to the plate or making a fresh batch of trypsin.

- Alternatively, greatly overtrypsinizing the cells will also be detrimental to cell health, so if the cells come off very easily with one squirt, try reducing the trypsinization time slightly.

Problem (Step 65): Cells exhibit poor viability the day after plating.

Solution: This problem is often associated with the PDL substrate. Try coating with PDL overnight at $4^{\circ} \mathrm{C}$ and ensure that the dishes dry well between the washes and the addition of cells. Alternatively, the cells may have been over- or undertrypsinized. If the cells were difficult to remove from the panning dishes, try increasing the trypsin concentration or time. Conversely, if the cells came off the dish extremely easily, try decreasing the trypsin concentration or time.

\section{RECIPES}

CNTF Stock $(10 \mu \mathrm{g} / \mathrm{mL})$

To prepare, dilute ciliary neurotrophic factor (CNTF; Peprotech 450-02) to $10 \mu \mathrm{g} / \mathrm{mL}$ with sterile $0.2 \%$ BSA in Dulbecco's phosphate-buffered saline (D-PBS; HyClone SH30264.01). Make $20-\mu \mathrm{L}$ aliquots, flash freeze in liquid nitrogen, and store $-80^{\circ} \mathrm{C}$.

\section{DMEM-SATO Base Growth Medium}

1. Combine the following:

\begin{tabular}{|c|c|c|}
\hline Reagent & $\begin{array}{l}\text { Amount } \\
\text { (for } 20 \mathrm{~mL})\end{array}$ & Final concentration \\
\hline $\begin{array}{l}\text { Dulbecco's Modified Eagle's Medium } \\
\text { (Invitrogen 11960-044) }\end{array}$ & $19.5 \mathrm{~mL}$ & $1 \times$ \\
\hline SATO supplement $(100 \times)<\mathrm{R}>$ & $200 \mu \mathrm{L}$ & $1 \times$ \\
\hline Glutamine (200 mm; Invitrogen 25030-081) & $200 \mu \mathrm{L}$ & $2 \mathrm{~mm}$ \\
\hline $\begin{array}{l}\text { Penicillin-streptomycin (Gibco/Life } \\
\text { Technologies 15140-122) }\end{array}$ & $200 \mu \mathrm{L}$ & $\begin{array}{r}100 \mathrm{U} / \mathrm{mL} \text { (penicillin) } 100 \\
\mu \mathrm{g} / \mathrm{mL} \text { (streptomycin) }\end{array}$ \\
\hline $\begin{array}{l}\text { Sodium pyruvate ( } 100 \mathrm{~mm} \text {; Invitrogen } \\
11360-070)\end{array}$ & $200 \mu \mathrm{L}$ & $1 \mathrm{~mm}$ \\
\hline Insulin stock $(0.5 \mathrm{mg} / \mathrm{mL})<\mathrm{R}>$ & $200 \mu \mathrm{L}$ & $5 \mu \mathrm{g} / \mathrm{mL}$ \\
\hline $\begin{array}{l}N \text {-Acetyl-L-cysteine (Sigma-Aldrich A8199) } \\
\text { stock }(5 \mathrm{mg} / \mathrm{mL} \text {, prepared in DMEM) }\end{array}$ & $20 \mu \mathrm{L}$ & $5 \mu \mathrm{g} / \mathrm{mL}$ \\
\hline Trace Elements B (1000×; Cellgro 99-175-CI) & $20 \mu \mathrm{L}$ & $1 \times$ \\
\hline d-Biotin (Sigma-Aldrich B4639) stock (50 & $4 \mu \mathrm{L}$ & $10 \mathrm{ng} / \mathrm{mL}$ \\
\hline
\end{tabular}

2. To improve viability of mouse OPCs and oligodendrocytes, include $400 \mu \mathrm{L}$ of $50 \times \mathrm{B}-27$ (Invitrogen 17504-044).

SM1 supplement (Stemcell Technologies 05711) or NS21 supplement (Chen et al. 2008; R\&D Systems AR008) may be used in place of B-27 to promote survival. Note that these commercially 
available supplements all contain small but biologically relevant amounts of T3. We have not found that this prevents expansion of cortical mouse OPCs for up to at least 2 wk in culture, however; if you wish to study OPCs in the absence of T3-mediated signaling, prepare NS21 lacking T3 as per Chen et al. (2008) or use rat OPCs (which do not require the supplements for survival).

3. Filter through a $0.22-\mu \mathrm{m}$ filter to sterilize. Store at $4^{\circ} \mathrm{C}$ for up to $1 \mathrm{wk}$.

\section{DNase I}

On ice, dissolve 12,500 U of DNase I (Worthington Biochemical LS002007) per $1 \mathrm{~mL}$ of chilled Earle's Balanced Salt Solution (EBSS; Invitrogen 14155-063). Filter-sterilize on ice. Aliquot (e.g., $200 \mu \mathrm{L} /$ tube) and freeze overnight at $-20^{\circ} \mathrm{C}$. Store aliquots at $-20^{\circ} \mathrm{C}$ to $-30^{\circ} \mathrm{C}$.

EBSS Stock $(10 \times)$

\begin{tabular}{lcc} 
Reagent & Quantity (for $250 \mathrm{~mL})$ & Final concentration $(10 \times)$ \\
\hline $\mathrm{NaCl}$ & $17 \mathrm{~g}$ & $1.16 \mathrm{M}$ \\
$\mathrm{KCl}$ & $1 \mathrm{~g}$ & $54 \mathrm{~mm}$ \\
$\mathrm{NaH}_{2} \mathrm{PO}_{4} \cdot \mathrm{H}_{2} \mathrm{O}$ & $0.35 \mathrm{~g}$ & $10 \mathrm{mM}$ \\
Glucose & $2.5 \mathrm{~g}$ & $1 \%$ \\
Phenol red $(0.5 \%)$ & $2.5 \mathrm{~mL}$ & $0.005 \%$
\end{tabular}

Bring to $250 \mathrm{~mL}$ with $\mathrm{ddH}_{2} \mathrm{O}$ and filter to sterilize.

\section{Ethanol-Washed Glass Coverslips}

Extensively wash 12-mm glass coverslips (Carolina Biological Supply 633029) in 70\% ethanol. Perform the washes on a platform shaker in a beaker, with enough motion to lightly agitate the coverslips but not break too many. Wash the coverslips for about $1 \mathrm{mo}$, exchanging the ethanol approximately every day. (It is fine to skip some exchanges.) Store the washed coverslips in $70 \%$ ethanol until use.

\section{Forskolin Stock $(4.2 \mathrm{mg} / \mathrm{mL})$}

To prepare, add $1 \mathrm{~mL}$ of sterile DMSO to a 50-mg bottle of forskolin (Sigma-Aldrich F6886) and pipette up and down until the powder is fully resuspended. Transfer to a $15-\mathrm{mL}$ conical tube and add an additional $11 \mathrm{~mL}$ of DMSO to achieve a final concentration of $4.2 \mathrm{mg} / \mathrm{mL}$. Store in 20 - and $80-\mu \mathrm{L}$ aliquots at $-20^{\circ} \mathrm{C}$.

\section{High-Ovomucoid Stock (6×)}

1. Dissolve the following in 160-180 mL of Dulbecco's phosphate-buffered saline (D-PBS; Invitrogen 14287-080).

\begin{tabular}{lcc} 
Reagent & Amount (for $200 \mathrm{~mL})$ & Final concentration \\
\hline BSA (Sigma_Aldrich A-8806) & $6 \mathrm{~g}$ & $30 \mathrm{mg} / \mathrm{mL}$ \\
Trypsin inhibitor (Worthington & $6 \mathrm{~g}$ & $30 \mathrm{mg} / \mathrm{mL}$
\end{tabular}

2. Adjust the $\mathrm{pH}$ to 7.4 with $10 \mathrm{~N} \mathrm{NaOH}$. Bring the volume to $200 \mathrm{~mL}$ with $\mathrm{D}-\mathrm{PBS}$, and then filter-sterilize.

3. Make $1-\mathrm{mL}$ aliquots and store them at $-20^{\circ} \mathrm{C}$. 
B. Emery and J.C. Dugas

\section{Insulin Stock $(0.5 \mathrm{mg} / \mathrm{mL})$}

To $20 \mathrm{~mL}$ of sterile water, add $10 \mathrm{mg}$ of insulin (Sigma-Aldrich I6634) and $100 \mu \mathrm{L}$ of $1.0 \mathrm{~N}$ HCl. Mix well. Filter through a $0.22-\mu \mathrm{m}$ filter. Store at $4^{\circ} \mathrm{C}$ for $4-6 \mathrm{wk}$.

\section{Low-Ovomucoid Stock Solution (10×)}

To prepare, add $3 \mathrm{~g}$ of BSA (Sigma-Aldrich A8806) to $150 \mathrm{~mL}$ D-PBS. Mix well. Add $3 \mathrm{~g}$ of trypsin inhibitor (Worthington LS003086) and mix to dissolve. Add $\sim 1 \mathrm{~mL}$ of $1 \mathrm{~N} \mathrm{NaOH}$ to adjust the $\mathrm{pH}$ to 7.4 . Bring the volume to $200 \mathrm{~mL}$ with D-PBS. Filter-sterilize through a $0.22-\mu \mathrm{m}$ filter. Make $1.0-\mathrm{mL}$ aliquots and store at $-20^{\circ} \mathrm{C}$.

\section{NT-3 Stock $(1 \mu \mathrm{g} / \mathrm{mL})$}

1. Prepare a master stock of neurotrophin-3 (NT-3; Peprotech 450-03) at $1-0.1 \mathrm{mg} / \mathrm{mL}$ according to manufacturer's instructions. (Instructions may vary from lot to lot; generally, NT-3 is dissolved in buffer [e.g., Dulbecco's phosphate-buffered saline] plus $0.2 \%$ BSA.) Store at $-80^{\circ} \mathrm{C}$.

2. Prepare $0.2 \%$ BSA (Sigma-Aldrich A4161) in Dulbecco's phosphate-buffered saline (D-PBS; Invitrogen 14287-080). Filter-sterilize and chill.

3. Dilute an aliquot of NT-3 master stock to $1 \mu \mathrm{g} / \mathrm{mL}$ in sterile, chilled $0.2 \%$ BSA prepared in Step 2.

4. Aliquot the NT-3 working stock from Step 3 (e.g., $20 \mu \mathrm{L} /$ tube) and snap-freeze in liquid nitrogen.

5. Store aliquots at $-80^{\circ} \mathrm{C}$.

\section{OPC Culture Medium}

1. To prepare full OPC culture medium, combine the following: $20 \mathrm{~mL}$ DMEM-SATO base growth medium $<\mathrm{R}>$

$20 \mu \mathrm{L}$ Forskolin stock $(4.2 \mathrm{mg} / \mathrm{mL})<\mathrm{R}>$

$20 \mu \mathrm{L}$ CNTF stock $(10 \mu \mathrm{g} / \mathrm{mL})<\mathrm{R}>$

2. Add growth factors as appropriate.

- To promote OPC proliferation, omit PDGF and add:

$20 \mu \mathrm{L}$ PDGF stock $(10 \mu \mathrm{g} / \mathrm{mL})<\mathrm{R}>$

$20 \mu \mathrm{L}$ NT-3 stock $(1 \mu \mathrm{g} / \mathrm{mL})<\mathrm{R}>$

- To promote OL differentiation, omit PDGF and add: $200 \mu \mathrm{L} \mathrm{T} 3$ stock $(4 \mu \mathrm{g} / \mathrm{mL})<\mathrm{R}>$

3. Store at $4^{\circ} \mathrm{C}$ for up to $3 \mathrm{~d}$.

Papain Buffer

\begin{tabular}{lcc} 
Reagent & Amount (for $250 \mathrm{~mL})$ & Final concentration \\
\hline EBSS stock $(10 \times)<\mathrm{R}>$ & $25 \mathrm{~mL}$ & $1 \times$ \\
$\mathrm{MgSO}_{4}(100 \mathrm{~mm})$ & $2.5 \mathrm{~mL}$ & $1 \mathrm{~mm}$ \\
Glucose $(30 \%)$ & $3 \mathrm{~mL}$ & $0.46 \%$ \\
EGTA $^{(0.5 \mathrm{M})}$ & $1 \mathrm{~mL}$ & $2 \mathrm{~mm}$ \\
$\mathrm{NaHCO}_{3}(1 \mathrm{~m})$ & $6.5 \mathrm{~mL}$ & $26 \mathrm{~mm}$
\end{tabular}

Bring volume up to $250 \mathrm{~mL}$ with $\mathrm{ddH}_{2} \mathrm{O}$ and filter to sterilize. 


\section{PDGF Stock $(10 \mu g / m L)$}

1. Prepare a platelet-derived growth factor (PDGF) master stock by diluting PDGF (Peprotech $100-13 \mathrm{~A}$ ) at $1-0.1 \mathrm{mg} / \mathrm{mL}$ according to manufacturer's instructions. (Instructions may vary from lot to lot; generally, PDGF is dissolved in buffer [e.g., Dulbecco's phosphate-buffered saline] plus $0.2 \%$ BSA.) Store at $-80^{\circ} \mathrm{C}$.

2. Prepare 0.2\% BSA (Sigma-Aldrich A4161) in Dulbecco's phosphate-buffered saline (D-PBS; Invitrogen 14287-080). Filter-sterilize and chill.

3. Dilute an aliquot of PDGF master stock to $10 \mu \mathrm{g} / \mathrm{mL}$ in sterile, chilled $0.2 \%$ BSA prepared in Step 2.

4. Aliquot the PDGF working stock from Step 3 (e.g., $20 \mu \mathrm{L} /$ tube) and snap-freeze in liquid nitrogen.

5. Store aliquots at $-80^{\circ} \mathrm{C}$.

Poly-D-Lysine (PDL) Stock $(1 \mathrm{mg} / \mathrm{mL})$

1. Resuspend poly-D-lysine (PDL; Sigma-Aldrich P6407; molecular weight 70-150 kDa) at $1 \mathrm{mg} / \mathrm{mL}$ in borate buffer by combining $50 \mathrm{mg}$ of PDL and $50 \mathrm{~mL}$ of $0.15 \mathrm{M}$ boric acid ( $\mathrm{pH} 8.4)$.

2. Filter to sterilize, and then aliquot (e.g., $100 \mu \mathrm{L} /$ tube). Store aliquots at $-20^{\circ} \mathrm{C}$.

\section{SATO Supplement (100×)}

1. Prepare the following stock solutions (these should be made fresh; do not reuse):

- Combine $5 \mathrm{mg}$ of progesterone (Sigma-Aldrich P8783) and $200 \mu \mathrm{L}$ of ethanol to make a progesterone stock solution.

- Combine $4 \mathrm{mg}$ of sodium selenite (Sigma-Aldrich S5261), $10 \mu \mathrm{L}$ of $1 \mathrm{~N} \mathrm{NaOH}$, and 10 mL of Dulbecco's modified Eagle's medium (DMEM; Gibco/Life Technologies 11960044) to make a sodium selenite stock solution.

2. Combine the following:

\begin{tabular}{lcc} 
Reagent & $\begin{array}{c}\text { Quantity } \\
\text { (for 200 mL) }\end{array}$ & $\begin{array}{c}\text { Final concentration } \\
(100 \times)\end{array}$ \\
\hline BSA (Sigma-Aldrich A4161) & $2 \mathrm{~g}$ & $10 \mathrm{mg} / \mathrm{mL}$ \\
Transferrin (Sigma-Aldrich T1147) & $2 \mathrm{~g}$ & $10 \mathrm{mg} / \mathrm{mL}$ \\
Putrescine (Sigma-Aldrich P5780) & $320 \mathrm{mg}$ & $1.6 \mathrm{mg} / \mathrm{mL}$ \\
Progesterone stock solution & $50 \mu \mathrm{L}$ & $6 \mu \mathrm{g} / \mathrm{mL}$ \\
Sodium selenite stock solution & $2 \mathrm{~mL}$ & $4 \mu \mathrm{g} / \mathrm{mL}$
\end{tabular}

3. Bring to a total volume of $200 \mathrm{~mL}$ in DMEM, and then filter-sterilize. Aliquot and store at $-20^{\circ} \mathrm{C}$.

\section{T3 Stock $(4 \mu \mathrm{g} / \mathrm{mL})$}

1. Dissolve $4 \mathrm{mg}$ of thyroid hormone (T3; Sigma-Aldrich T6397) in $500 \mu \mathrm{L}$ of $1 \mathrm{~N} \mathrm{NaOH}$ to prepare a solution of $0.8 \mathrm{mg} / 100 \mu \mathrm{L}$.

2. Add $75 \mu \mathrm{L}$ of the T3 solution from Step 1 to $150 \mathrm{~mL}$ of Dulbecco's phosphate-buffered saline (D-PBS; Invitrogen 14287-080).

3. Filter solution through a filter-sterilization unit, discarding the first $10 \mathrm{~mL}$.

4. Aliquot (e.g., $200 \mu \mathrm{L} /$ tube) and then store at $-20^{\circ} \mathrm{C}$. 
B. Emery and J.C. Dugas

\section{REFERENCE}

Chen Y, Stevens B, Chang J, Milbrandt J, Barres BA, Hell JW. 2008. NS21: Re-defined and modified supplement B27 for neuronal cultures. J Neurosci Methods 171: 239-247. 


\section{Purification of Oligodendrocyte Lineage Cells from Mouse Cortices by Immunopanning}

Ben Emery and Jason C. Dugas

Cold Spring Harb Protoc; doi: 10.1101/pdb.prot073973

\begin{tabular}{|c|c|}
\hline $\begin{array}{r}\text { Email Alerting } \\
\text { Service }\end{array}$ & Receive free email alerts when new articles cite this article - click here. \\
\hline $\begin{array}{l}\text { Subject } \\
\text { Categories }\end{array}$ & $\begin{array}{l}\text { Browse articles on similar topics from Cold Spring Harbor Protocols. } \\
\text { Immunoaffinity Purification ( } 49 \text { articles) } \\
\text { Immunoseparation ( } 31 \text { articles) } \\
\text { Mouse ( } 437 \text { articles) } \\
\text { Neural Cell Culture (57 articles) } \\
\text { Neuroscience, general ( } 357 \text { articles) } \\
\text { Other Laboratory Organisms ( } 68 \text { articles) }\end{array}$ \\
\hline
\end{tabular}

